\title{
Avaliação sazonal da qualidade das águas subterrâneas da Bacia do Córrego Fundo, Aquidauana-MS
}

\author{
Nanci Cappi ${ }^{*}$ \\ Tânia Mara Baptista dos Santos \\ André Alves de Oliveira ${ }^{* * *}$ \\ André Luiz Pinto ${ }^{* * *}$ \\ Lucy Ribeiro Ayach ${ }^{* * * *}$
}

\section{Resumo}

Objetivou-se avaliar sazonalmente a qualidade das águas subterrâneas da Bacia do Córrego Fundo através da análise da água de sete poços distribuídos na bacia, utilizando-se de variáveis indicadoras como: alcalinidade total, cloreto, $\mathrm{pH}$ e coliformes totais e fecais (Número Mais Provável $/ \mathrm{mL}$ ), além das características construtivas dos poços. Observou-se a influência da sazonalidade nas concentrações médias de alcalinidade, cloreto e $\mathrm{pH}$. A alcalinidade apresentou-se elevada nas estações secas e o cloreto reduzido em todos os poços. Em função da alcalinidade elevada no período seco o $\mathrm{pH}$ também apresentou uma ligeira elevação. O NMP de bactérias coliformes também sofreu a influência da sazonalidade, com valores elevados no período chuvoso. De acordo com as Legislações Vigentes, com exceção do

* Professora da Universidade Estadual de Mato Grosso do Sul - Unidade Universitária de Aquidauana (nccappi@uems.br).

** Professora da Universidade Estadual de Mato Grosso do Sul - Unidade Universitária de Aquidauana (tania@uems.br).

*** Mestrando em Ciência Animal - FAMEV - Universidade Federal de Mato Grosso-MT.

Professor da Universidade Federal de Mato Grosso do Sul CPTL/DCH/Unidade II (andreluiz@cptl.ufms.br).

Professora da Universidade Federal de Mato Grosso do Sul UFMS/DGC, Campus de Aquidauana (luayach@terra.com.br).

Geosul, Florianópolis, v. 25, n. 50, p 151-174, jul./dez. 2010 
CAPPI, N. et al. Avaliação sazonal da qualidade das águas subterrâneas da ...

poço $\mathrm{P} 1$, os demais indicaram que suas águas estão impróprias para o consumo humano. Para os demais usos, considerando o NMP de bactérias termotolerantes acumuladas nas estações, somente no período seco a água estaria própria para o consumo específico de irrigação e dessedentação animal.

Palavras-chave: Coliformes termotolerantes; Concentração de cloreto; Indicadores de contaminação.

Seasonal evaluation of the groundwater quality in the Fundo River Basin, Aquidauana-MS Brazil

\section{Abstract}

The seasonal quality of the groundwater in the Fundo river basin based on water analysis of seven wells distributed along the basin was evaluated. The variable indicators evaluated: total alkalinity, chloride, $\mathrm{pH}$ and total and fecal coliforms (Most Probable Number $/ \mathrm{mL}$ ). Also were considered the well's constructive characteristics. It was observed seasonal influence in the average concentrations of alkalinity, chloride and $\mathrm{pH}$. The alkalinity presented high concentration in the dry seasons and reduced concentration of chloride in all wells. Because of the high concentration of alkalinity in the dry period, $\mathrm{pH}$ also presented slight elevation. MPN of coliforms bacteria also suffered the seasonal influence with high value in the rainy period. According to the Brazilian Legislation, excepting well P1, the others presented improper water to human consume. To the other ones uses, considering the MPN of thermotolerants bacteria accumulated in the seasons, just in the dry period the water would be proper to the specific use in irrigation and animal drinking.

Key words: Chloride concentration; Indicators of contamination; Thermotolerant coliforms. 
CAPPI, N. et al. Avaliação sazonal da qualidade das águas subterrâneas da ...

\section{Introdução}

Os ambientes aquáticos são utilizados em todo o mundo com distintas finalidades, entre as quais se destacam o abastecimento para consumo humano, a geração de energia, a irrigação, a aqüicultura e atividade de pesca, a navegação e a harmonia paisagística. No entanto, esse precioso recurso vem sendo ameaçado pelas ações indevidas do homem, o que acaba resultando em prejuízo para a própria humanidade (MORAES e JORDÃO, 2002).

Nas últimas décadas tem aumentado a preocupação com a qualidade da água no Brasil. À proporção que a população, a indústria e a agricultura crescem, aumenta a demanda, aliada à ausência de medidas conservacionistas e o uso pouco racional contribuem para a diminuição da oferta de água de boa qualidade. Neste contexto, reforça Rebouças (2001) que a água é um recurso natural renovável, limitado, de valor econômico, que se usa e é devolvida ao ambiente com sua característica natural, quantidade ou qualidade, diminuída pelo uso. Contudo, a autodepuração pode chegar a estágio de exaustão que certamente diminuirá a oferta desse recurso em volume e qualidade para a satisfação das necessidades humanas.

A ocupação antrópica irregular das bacias produzem alterações nas características físicas, químicas e biológicas dos sistemas aquáticos, conduzindo ao desequilíbrio da fauna e flora dos corpos d'água, resultando em prejuízos para as comunidades que residem e dependem economicamente dos recursos hídricos disponíveis na bacia.

A ação do homem no ambiente está intimamente ligada à qualidade dos recursos hídricos e todas as mudanças refletem em uma série de alterações que afeta o equilíbrio do sistema natural. Para Baganha (1996), a contaminação das águas ocorre quando os meios hídricos recebem resíduos sólidos e/ou líquidos, agrotóxicos e fertilizantes utilizados nas lavouras, ou ainda quando partículas em suspensão na atmosfera são carreadas ao solo pela ação de 
CAPPI, N. et al. Avaliação sazonal da qualidade das águas subterrâneas da ...

precipitações pluviométricas e estas afetam a qualidade das águas; já a poluição é qualquer modificação do meio, causada por contaminantes, tornando-o ofensivo para a saúde e para a natureza, prejudicando assim o equilíbrio natural. Portanto, contaminação e poluição podem estar associadas a uma mesma origem, a introdução de resíduos estranhos à natureza do ambiente aquático. Esses resíduos são comumente de natureza complexa e contém substâncias que prejudicam ecologicamente o meio e, ao mesmo tempo, elementos nocivos para a saúde do homem e dos animais terrestres (ALVARES, 2000).

Segundo relatório das Nações Unidas, cerca de um terço da população do planeta vive em países que já apresentam alguma deficiência no suprimento de água doce; esta proporção atingirá provavelmente dois terços no ano 2025 (BAIRD, 2002).

Embora diversos fatores possam comprometer a qualidade das águas subterrâneas, o destino final do esgoto doméstico e industrial, a disposição inadequada de resíduos sólidos urbanos e industriais e a modernização da agricultura representam fontes de contaminação por bactérias e vírus patogênicos, parasitas, substâncias orgânicas e inorgânicas (SILVA e ARAÚJO, 2003). Mesmo assim, devido à sua infiltração através do solo e ao longo tempo que permanecem no subsolo, têm sido consideradas tradicionalmente como uma fonte pura e segura de água para consumo humano, sobretudo, para as populações de áreas rurais e as que não têm acesso à rede pública de abastecimento ou para aqueles que, tendo acesso a uma rede de abastecimento, têm o fornecimento com freqüência irregular.

O fenômeno de contaminação de aqüífero é motivo de grandes preocupações, pois segundo Setti et al. (2001), a água pode demorar até 1400 anos para se renovar fazendo com que muitos aqüíferos se percam. Considerando os aqüíferos como corpos tridimensionais, em geral extensos e profundos, a poluição capaz de atingir as águas subterrâneas pode ter origem variada. Morais (1996) destaca que os efluentes urbanos e industriais, agricultura, fossas sépticas, vazamento de tubulações de esgotos, aterros 
CAPPI, N. et al. Avaliação sazonal da qualidade das águas subterrâneas da ... sanitários, lagoas de oxidação e irrigação com águas usadas ou contaminadas, lixos domésticos e industriais depositados próximos, ou em contato com águas superficiais e outras, como formas de contaminação. Pinto (1998) associa as fontes de poluição com origem nos efluentes domésticos, deflúvios superficial urbano e agrícola e ao tipo de uso e ocupação do solo.

Nas águas, do ponto de vista sanitário, o que realmente põe em risco a saúde pública é a ocorrência de poluição fecal, pela possibilidade de estarem presentes também microrganismos patogênicos intestinais, como bactérias, vírus, protozoários e ovos de helmintos, agentes freqüentemente responsáveis por doenças de veiculação hídrica (GELDREICH, 1974).

As fontes de contaminação das águas subterrâneas são diversas e podem originar compostos químicos, orgânicos e inorgânicos e, especialmente, bactérias do grupo coliformes. Os coliformes são bactérias utilizadas como indicadoras de qualidade higiênico-sanitária, destacando-se os coliformes fecais, que são indicadores de contaminação fecal (MENDONÇA e GRANADA, 1999).

A presença de coliformes pode ou não indicar contaminação fecal. A verificação se um corpo d'água é portador de agentes de doenças pode ser feita de forma indireta, mediante organismos indicadores de contaminação fecal. $\mathrm{O}$ despejo dos efluentes de animais quando alcançam as águas superficiais e subterrâneas podem ser fontes de doenças causadas por coliformes, leptospirose, tularemia, febre aftosa, hepatite, peste suína clássica e etc. Alguns coliformes como a E.coli, manifestando certa patogenicidade para pessoas adultas e animais, podem ser fatais para as crianças (OLIVEIRA, 1994).

O subgrupo coliforme fecal está constituído, em especial, por Escheria coli e sua detecção indica poluição fecal proveniente de fezes humanas. Mesmo não havendo uma relação quantitativa entre indicadores biológicos e microrganismos patogênicos, a probabilidade de se encontrar bactérias patogênicas na água é maior quanto maior forem os números de coliformes fecais presentes nesta água (DMAE, 2001). 
CAPPI, N. et al. Avaliação sazonal da qualidade das águas subterrâneas da ...

Os coliformes estão presentes em grandes quantidades nas fezes do ser humano e dos animais de sangue quente, pois, são enterobactérias comumente encontradas no trato intestinal destes indivíduos. Elas também podem ser isoladas do solo, água e vegetais (VANDERZANT e SPLITTSTOESSER, 1992). A presença de coliformes na água não representa por si só, um perigo à saúde, mas indica a possível presença de outros organismos causadores de problemas. Os principais indicadores de contaminação fecal são as concentrações de coliformes totais e fecais, expressa em número de organismos por $100 \mathrm{~mL}$ de água.

As comunidades rurais têm como fontes principais de abastecimento de água os poços e as nascentes; fontes bastante susceptíveis à contaminação, já que os poços são normalmente rasos e não seguem as normas técnicas de construção e as nascentes muitas vezes servem também como bebedouro para os animais. A evidência dessas características relativamente comuns em comunidades rurais expõe essas áreas à contaminação hídrica, podendo apresentar fontes pontuais de contaminação de origem antrópica, resultante do uso inadequado do solo e das más condições das instalações das fontes de captação de água.

Deste modo, em consequiência da demanda crescente do uso das águas subterrâneas, notadamente, em área rural, justifica-se a intensificação de estudos para determinar a qualidade desses recursos em áreas com predominante atividade agropecuária, por meio de variáveis indicadoras de contaminação e das características dos poços.

\section{Localização e caracterização da área de estudo}

A bacia do Córrego Fundo localiza-se entre as coordenadas geográficas de $20^{\circ} 23$ ' 59" a $20^{\circ} 28^{\prime} 36^{\prime \prime}$ de latitude Sul e $55^{\circ} 37^{\prime \prime}$ $17^{\prime}$ a $55^{\circ} 41^{\prime} 46^{\prime}$ "de longitude WGR, e ocupa uma área de aproximadamente 2.874 ha, drenando terrenos do Planalto de Maracaju/Campo Grande até a Depressão do Rio 
CAPPI, N. et al. Avaliação sazonal da qualidade das águas subterrâneas da ...

Miranda/Aquidauana encontrando-se acerca de $11 \mathrm{~km}$ a leste do Município de Aquidauana - MS.

O município de Aquidauana possui duas estações climáticas bem definidas, a chuvosa (outubro a março) e a seca (abril a setembro), que segundo a classificação de Köppen enquadra-se no tipo AW, definido como clima tropical úmido. Possui precipitação média anual em torno de $1350 \mathrm{~mm}$ (SANT'ANNA NETTO, 1993). Geralmente a média térmica da região é alta, ficando em torno de $25^{\circ} \mathrm{C}$, ao passo que a média mensal do mês mais quente (janeiro) alcança $27,5^{\circ} \mathrm{C}$ e a do mês mais frio (junho) chega a $22,5^{\circ} \mathrm{C}$. Entretanto, são comuns na região temperaturas superiores a $40^{\circ} \mathrm{C}$ nos meses de verão e, nos meses de inverno, temperaturas mínimas de menos de $5^{\circ} \mathrm{C}$ (PINTO, 1998).

A bacia do córrego Fundo encontra-se geologicamente nas escarpas da Cuesta Arenítica Basáltica da Borda Ocidental da Bacia do Paraná, Serra de Maracaju/Campo Grande, no trecho localmente denominado de Serra de Santa Bárbara, à Depressão do rio Aquidauana, recobertas por terrenos da Formação Aquidauana.

O Córrego Fundo constitui-se em uma sub-bacia do rio Aquidauana em seu médio curso. Está situado numa área de domínio do Aqüífero da Bacia Sedimentar do Paraná ou denominado Aqüífero Guarani, que compreende o sistema de aqüífero Bauru-Caiuá, Serra Geral, Botucatu-Pirambóia, rio do Rastro e Aquidauana, com um volume estocado de água de 50.400 km3 (LEAL, 1999).

O Córrego Fundo nasce no front da cuesta Arenítica da Serra de Maracaju e corre em sentido NE/SW, até a confluência com seu principal afluente pela margem esquerda, o Córrego Ana Lu, que tem o mesmo sentido predominante. Após a confluência o Córrego Fundo verte em direção N/S até a foz com o rio Aquidauana.

\section{Materiais e métodos}

As amostras de água foram coletadas em sete poços selecionados nas propriedades localizadas na bacia do córrego 
CAPPI, N. et al. Avaliação sazonal da qualidade das águas subterrâneas da ...

Fundo (Figura 1). As informações sobre as características dos poços foram obtidas utilizando-se questionário aplicado nas propriedades. Essas informações, juntamente com os resultados das análises microbiológicas e físico-químicas, subsidiaram a avaliação sazonal no ano de 2004 nas estações do verão a primavera, nos pontos de coleta (poços) selecionados na seqüência da nascente para a foz como: poço (P1) coordenadas 20²5'959''S e $55^{\circ} 40^{\prime} 561^{\prime \prime} \mathrm{W}$, localizado próximo da nascente na Fazenda Santa Maria; (P2) $20^{\circ} 27^{\prime} 54^{\prime} ' \mathrm{~S}$ e $55^{\circ} 40^{\prime} 778^{\prime \prime} \mathrm{W}$, localizado no médio curso do córrego Fundo na Fazenda São Luiz; (P3) 2082'02'’S e 55 35'670' 'W, na Fazenda UEMS (Universidade Estadual de Mato Grosso do Sul) no médio curso do córrego; (P4) 20²8'344''S e 55 40 '382' 'W, na Fazenda UEMS localizado a margem direita da

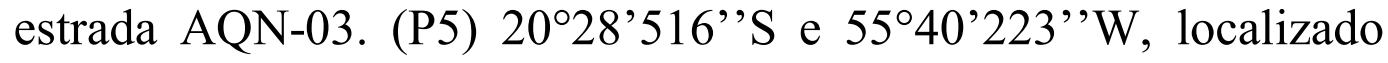
na Chácara São Luiz à margem direita da rodovia Estadual MS-450 que liga a cidade de Aquidauana ao Distrito de Camisão; (P6) $20^{\circ} 27^{\prime} 078^{\prime} ' S$ e $55^{\circ} 40^{\prime} 570^{\prime} ' \mathrm{~W}$, na Fazenda UEMS à margem direita da rodovia Estadual MS-450 e a esquerda do córrego

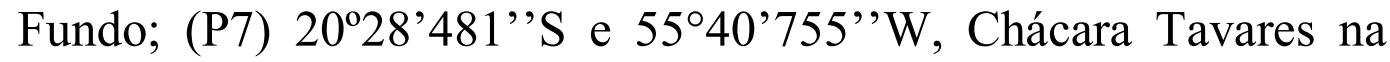
Foz do córrego Fundo com o rio Aquidauana

As coletas e preservação das amostras foram realizadas de acordo com APHA (1995). Os dados de pH através do pHmeter Model $420^{\mathrm{A}}$, a alcalinidade total pelo método titulométrico APHA (1995); cloreto por Mohr-titulométrico de nitrato de prata. As análises bacteriológicas através da técnica de Tubos Múltiplos e os resultados expressos em Número Mais Provável de Coliformes Totais e Fecais (NMP/100 mL), com base na metodologia descrita por SOARES e MAIA (1999).

A resolução CONAMA 396 de 2008 que estabelece valores para enquadramento das águas subterrâneas no Brasil, CONAMA 357 de 2005 e portaria 518 de 2004 do Ministério da Saúde, que apresentam os parâmetros para avaliar a potabilidade, subsidiaram a avaliação e interpretação dos resultados, visto que as águas destes poços são consumidas, dentre diversos usos, domesticamente para consumo humano. 
CAPPI, N. et al. Avaliação sazonal da qualidade das águas subterrâneas da ...

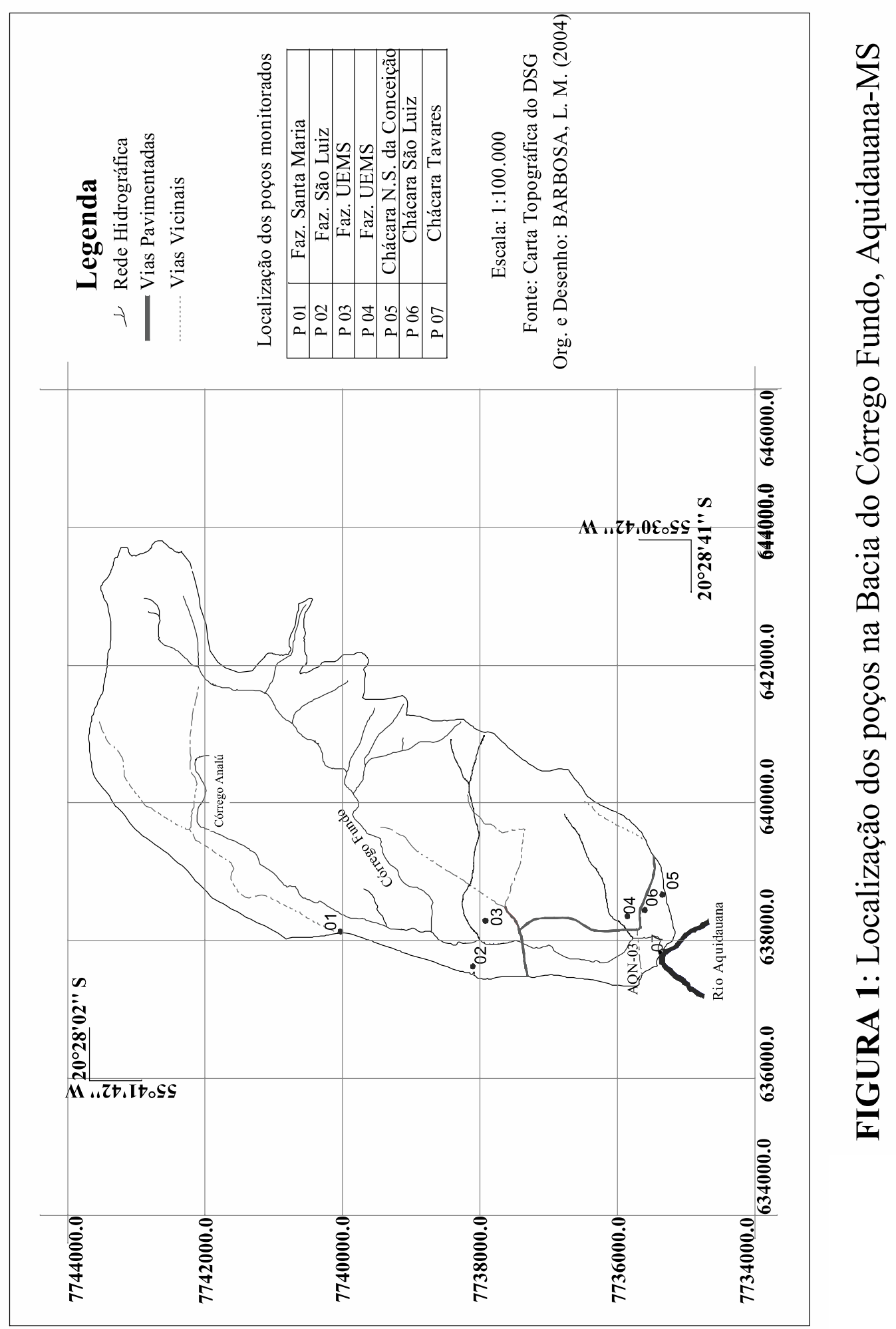

Geosul, v.25, n.50, 2010 
CAPPI, N. et al. Avaliação sazonal da qualidade das águas subterrâneas da ...

\section{Resultados e discussão}

\section{Características dos poços analisados}

A estrutura física dos poços, a manutenção e sua localização na propriedade são características importantes que estão diretamente ligadas à saúde das pessoas que consomem a água, especialmente as crianças que estão mais expostas às doenças de veiculação hídrica. Dos sete poços selecionados apenas dois (P1 e P3) eram do tipo tubular e cinco (P2, P4, P5, P6, e P7) construídos escavados manualmente totalizando $71,4 \%$ (Tabela 1). Os poços escavados são a forma mais difundida de captação de água do lençol freático nas comunidades rurais. São construídos por meio de uma escavação manual do solo, com um diâmetro de aproximadamente um metro e recebe a denominação técnica de poço raso ou poço freático.

Os dois poços tubulares (P1 e P3) e um escavado (P7), perfazendo $42,8 \%$ dos poços, captavam água por bombeamento, sistema seguro desde que o reservatório de água esteja em condições adequadas de higiene e o poço escavado vedado com tampa de concreto e cobertura externa. Os demais poços escavados P2, P4, P5 e P6 (57,0\%) utilizavam balde para captar a água. Nesse sistema geralmente ocorre contaminação devido às condições precárias da estrutura externa do poço freático e do coletor (balde) que não é higienizado antes de ser levado para dentro do poço.

A profundidade é outra característica importante, notadamente, nessa região em que a maioria dos poços não chega a $20 \mathrm{~m}$. Dos poços $42,8 \%$ possui profundidade de 0 a $10 \mathrm{~m}, 28,6 \%$ de 11 a $20 \mathrm{~m}$ e $28,6 \%$ acima de $20 \mathrm{~m}$. Os poços freáticos e escavados que possuem diâmetro maior e condições externas inadequadas estão susceptíveis à contaminação, sobretudo, no período chuvoso, quando são carreados através da percolação rápida da água no solo, os contaminantes biológicos e químicos da superfície até o lençol freático.

Cerca de $71,4 \%$ dos poços não possuíam proteção externa, permaneciam abertos permitindo que folhas e sujeiras trazidas pelo 
CAPPI, N. et al. Avaliação sazonal da qualidade das águas subterrâneas da ... vento e pelos objetos que normalmente são colocados na parte externa, atinjam a água favorecendo a contaminação.

A cobertura do poço além de proteger a estrutura externa evitando que a água da chuva carregue a sujeira para dentro do poço, impede a entrada do escoamento superficial que pode, em muitos casos, provocar o desmoronamento das paredes em poços que não possuem revestimento interno.

TABELA 1: Características dos poços selecionados para análise na bacia do córrego Fundo

\begin{tabular}{|c|c|c|c|c|c|c|c|c|c|}
\hline \multirow{2}{*}{\multicolumn{2}{|c|}{ Características }} & \multicolumn{7}{|c|}{ Poços } & \multirow{2}{*}{$\%$} \\
\hline & & P1 & $\mathbf{P 2}$ & P3 & P4 & P5 & P6 & P7 & \\
\hline \multirow{2}{*}{ Tipo de poço } & Escavado & & $\mathrm{x}$ & & $\mathrm{x}$ & $\mathrm{x}$ & $\mathrm{x}$ & $X$ & 71,4 \\
\hline & Tubular & $\mathrm{x}$ & & $\mathrm{x}$ & & & & & 28,6 \\
\hline \multirow{2}{*}{$\begin{array}{l}\text { Formas de } \\
\text { captação de água }\end{array}$} & Bombeamento & $\mathrm{x}$ & & $\mathrm{x}$ & & & & $\mathrm{X}$ & 42,8 \\
\hline & Manual com balde & & $\mathrm{x}$ & & $\mathrm{x}$ & $\mathrm{x}$ & $\mathrm{x}$ & & 57,0 \\
\hline \multirow{3}{*}{ Profundidade (m) } & 0 a 10 & $\mathrm{x}$ & & & $\mathrm{x}$ & & $\mathrm{x}$ & & 42,8 \\
\hline & 11 a 20 & & & & & $\mathrm{x}$ & & $\mathrm{X}$ & 28,6 \\
\hline & $>20$ & & $\mathrm{x}$ & $\mathrm{x}$ & & & & & 28,6 \\
\hline \multirow{3}{*}{$\begin{array}{l}\text { Distância entre o } \\
\text { poço e a fossa }(\mathrm{m})\end{array}$} & 0 a 10 & & & & & & $\mathrm{x}$ & & 14,3 \\
\hline & 11 a 20 & & $\mathrm{x}$ & & $\mathrm{x}$ & $\mathrm{x}$ & & $\mathrm{X}$ & 57,0 \\
\hline & $>20$ & $\mathrm{x}$ & & $\mathrm{x}$ & & & & & 28,6 \\
\hline \multirow{2}{*}{ Cobertura externa } & Sim & $\mathrm{x}$ & & $\mathrm{x}$ & & & & & 28,6 \\
\hline & Não & & $\mathrm{x}$ & & $\mathrm{x}$ & $\mathrm{x}$ & $\mathrm{x}$ & $\mathrm{X}$ & 71,4 \\
\hline
\end{tabular}

Outro fator importante que deve ser considerado é a localização do poço na propriedade em relação as atividades potencialmente contaminantes como: fossas, horta, pomar, depósito de lixo, galinheiros, estábulos, pocilgas, entre outros. Dos poços analisados 14,3\% localizam-se de 0 a $10 \mathrm{~m}$ de distância de uma fossa, 57\% de 11 a $20 \mathrm{~m}$ e 28,6\% 
CAPPI, N. et al. Avaliação sazonal da qualidade das águas subterrâneas da ... possuem distância acima de $20 \mathrm{~m}$. Observou-se que os proprietários rurais não têm preocupações com a distância do poço em relação à fossa, dependência dos animais, deposição de lixo e horta, tudo é instalado muito próximo da casa e, consequentemente, do poço para facilitar o manejo diário dessas atividades. Logo, são fatores que podem comprometer a qualidade das águas subterrâneas em comunidades rurais, poços rasos, formações hidrogeológicas porosas ou falhas, disposição final do esgoto doméstico e agropecuários ou agroindustriais, fossa construída próximo e a montante do poço, disposição inadequada do lixo, cultivo de horta, jardim e pomar utilizando adubo derivado de dejetos de animais, bem como, poços construídos nas dependências das casas permitindo a utilização da parte externa da estrutura para acomodar vasilhas e utensílios domésticos ou agropecuários, facilitando dessa forma a contaminação das águas.

\section{Qualidade das águas dos poços.}

A qualidade da água para consumo humano é estabelecida em função dos Valores Máximos Permitidos (VMP) para as variáveis físicas, químicas e biológicas e deve se enquadrar de acordo com padrões estabelecidos segundo as normas do Ministério da Saúde PORTARIA No 518, de 25 de março de 2004 (BRASIL, 2004) e do Conselho Nacional de Meio Ambiente (CONAMA) Resolução N ${ }^{\circ}$ 396 de 3 de abril de 2008 (BRASIL, 2008).

Considerando que a água de poço em comunidades rurais também é utilizada para irrigação de hortas caseiras e para dessedentação animal, o uso de água para esses fins é regulamentado pelo CONAMA Resolução No 357 , de 17 de março de 2005, que dispõe sobre a classificação dos corpos d'água visando os diferentes usos (BRASIL, 2005).

As concentrações de alcalinidade total elevadas nos poços P4, P5 e P6, podem ter origem em função das características 
CAPPI, N. et al. Avaliação sazonal da qualidade das águas subterrâneas da ... hidrogeoquimicas da formação Aquidauana e ao ambiente de deposição, já que esses poços, estão localizados no baixo curso, próximos à foz no rio Aquidauana (Figura 1). As condições sanitárias desses poços também podem ter influenciado. Considerando que, são do tipo escavado, rasos, próximo de fossa e sem cobertura externa (Tabela 1)

Segundo Richter e Azevedo Neto (1991) valores elevados de alcalinidade total são devidos à presença de substâncias como silicatos, fosfatos de sais orgânicos e ácidos húmicos, embora os principais sejam carbonatos, bicarbonatos e os hidróxidos. A presença dessas substâncias na água está diretamente relacionada ao $\mathrm{pH}$. As águas que apresentarem $\mathrm{pH}$ na faixa de 4,6 a 8,3, a alcalinidade total é devido à presença somente de bicarbonato. Como o $\mathrm{pH}$ no período analisado teve como valor mínimo 5,8 no P1 e máximo de 8,3 no $\mathrm{P} 2$ no inverno, concluiu-se que a alcalinidade total é devido à presença somente de bicarbonatos. O VMP para a alcalinidade em bicarbonatos é de $250 \mathrm{mgL}^{-1}$ (APHA, 1989), os poços $\mathrm{P} 4$ em todas as estações analisadas, P5 no outono, inverno e primavera e P6 no verão e outono, ultrapassaram esse valor.

As concentrações de cloreto foram superiores a $100 \mathrm{mgL}^{-1}$ em todos os poços no verão mas, inferiores ao VMP de $250 \mathrm{mgL}^{-1}$ (BRASIL, 2004) e (BRASIL, 2008). Nesta estação os poços que apresentaram concentrações elevadas foram, P3 com 222,4 $\mathrm{mgL}^{-1}$; P4 com 144,9 $\mathrm{mgL}^{-1}$ e P7 com $154,9 \mathrm{mgL}^{-1}$. Na primavera com exceção do $\mathrm{P} 1$ com $57,5 \mathrm{mgL}^{-1}$, todos apresentaram concentrações elevadas e se destacaram os poços P3 com 150,0 $\mathrm{mgL}^{-1}$; P6 com $140,0 \mathrm{mgL}^{-1}$ e P7 com $142,5 \mathrm{mgL}^{-1} 1$ e no outono e inverno todos os poços, apresentaram concentrações inferior a $100 \mathrm{mgL}^{-1}$ com exceção do P3 com 145,0 $\mathrm{mgL}^{-1}$.

A elevada concentração de cloreto do poço P3 com 222,4 $\mathrm{mgL}^{-1}$, próximo do $\mathrm{VMP}$, pode estar relacionada à sua localização na propriedade, mesmo apresentando condições construtivas adequadas, do tipo tubular, com cobertura externa, distante de fossa e 90 metros de profundidade (Tabela 1). Mas está localizado em área de declividade acentuada, que recebe o escoamento 
CAPPI, N. et al. Avaliação sazonal da qualidade das águas subterrâneas da ... proveniente de uma área de lavoura e de uma horta, com várias culturas irrigadas e uso de adubo orgânico e químico, contribuindo dessa forma para o acúmulo de íons cloreto.

TABELA 2: Valores de Alcalinidade, Cloreto e pH encontrados nas águas dos poços na bacia do córrego Fundo em 2004.

\begin{tabular}{|c|c|c|c|c|c|c|c|c|}
\hline \multirow{2}{*}{ 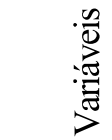 } & \multirow[b]{2}{*}{ Estações } & \multicolumn{7}{|c|}{ Poços } \\
\hline & & P1 & P2 & $\mathbf{P 3}$ & P4 & P5 & P6 & P7 \\
\hline \multirow{4}{*}{ 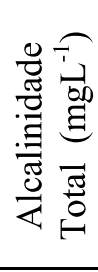 } & Verão & 17,8 & 163,0 & 65,0 & 416,9 & 181,1 & 525,3 & 51,0 \\
\hline & Outono & 15,3 & 165,8 & 178,5 & 511,3 & 413,1 & 423,3 & 164,5 \\
\hline & Inverno & 16,3 & 188,7 & 15,8 & 468,7 & 447,0 & 164,9 & 44,5 \\
\hline & Primavera & 12,4 & 124,2 & 122,4 & 422,2 & 338,8 & 124,2 & 30,2 \\
\hline \multirow{4}{*}{ 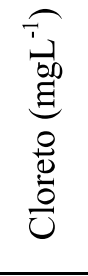 } & Verão & 102,5 & 107,5 & 222,4 & 144,9 & 127,5 & 127,5 & 154,9 \\
\hline & Outono & 34,9 & 50,0 & 60,0 & 35,0 & 90,0 & 54,9 & 70,0 \\
\hline & Inverno & 54,9 & 65,0 & 145,0 & 95,0 & 95,0 & 80,0 & 75,0 \\
\hline & Primavera & 57,5 & 132,5 & 15,0 & 130,5 & 114,9 & 140,0 & 142,5 \\
\hline \multirow{4}{*}{$\stackrel{T}{2}$} & Verão & 5,6 & 7,8 & 6,6 & 7,7 & 7,8 & 6,5 & 7,6 \\
\hline & Outono & 6,3 & 8,2 & 7,4 & 7,6 & 7,6 & 8,0 & 6,7 \\
\hline & Inverno & 5,8 & 8,3 & 7,9 & 7,6 & 7,5 & 7,4 & 6,1 \\
\hline & Primavera & 6,1 & 7,4 & 7,9 & 7,5 & 7,6 & 7,1 & 6,1 \\
\hline
\end{tabular}

Teores elevados de cloretos em água de consumo humano podem trazer restrições ao sabor, aumentar a corrosividade de tubos e estruturas metálicas e ainda provocar reações fisiológicas (BRIGANTE et al., 2003)

Considerando que o $\mathrm{pH}$ em água para consumo humano deve estar na faixa de 6,0 a 9,5 (BRASIL, 2004) e para irrigação (Classe 2) e dessedentação animal (Classe 3) 6,0 a 9,0 (BRASIL, 2005), todas as amostras estão dentro da faixa exigida com exceção 
CAPPI, N. et al. Avaliação sazonal da qualidade das águas subterrâneas da ... do poço P1 com 5,6 no verão e 5,8 no inverno, portanto abaixo do limite inferior da faixa permitida.

De acordo com a figura 2, observou-se a influência da sazonalidade nos valores médios das concentrações de alcalinidade total, os quais apresentaram-se elevados nas estações secas do ano, outono e inverno, e inferiores nas estações chuvosas, primavera e verão. No período seco o lençol freático é abastecido com água proveniente das áreas de recarga, portanto, a elevação das concentrações tem origem nas características do substrato rochoso, ao passo que no período chuvoso ocorre uma diluição dessas concentrações em função do aumento da disponibilidade de água originária do escoamento superficial.

Observou-se também uma dinâmica diferenciada no comportamento das concentrações dos íons cloretos e da alcalinidade total. Ao passo que a alcalinidade total apresentou-se elevada nas estações secas do ano, as concentrações de cloretos foram reduzidas. As concentrações relativamente elevadas de cloretos em todos os poços no verão e primavera podem ter origem no uso e ocupação do solo da bacia. Segundo TURKEWICZ (2005), em 2002 a bacia do córrego Fundo possuía 56,47\% de sua área ocupada por pastagens cultivadas, nem sempre adequadas ao tipo de solo, gerando com isso processo de ravinamento e posteriormente erosões, em especial no alto curso da bacia, facilitando a lixiviação e consequentemente, o acúmulo de substâncias químicas no lençol freático. Considerando que os íons cloretos formam compostos muito solúveis e estáveis, do ponto de vista químico e migram da superfície para níveis mais profundos e, lateralmente, sem sofrerem mudanças (BARCHA, 1997), dessa forma, podem estar sendo acumulados nessas águas oriundas das regiões mais elevadas. 
CAPPI, N. et al. Avaliação sazonal da qualidade das águas subterrâneas da ...

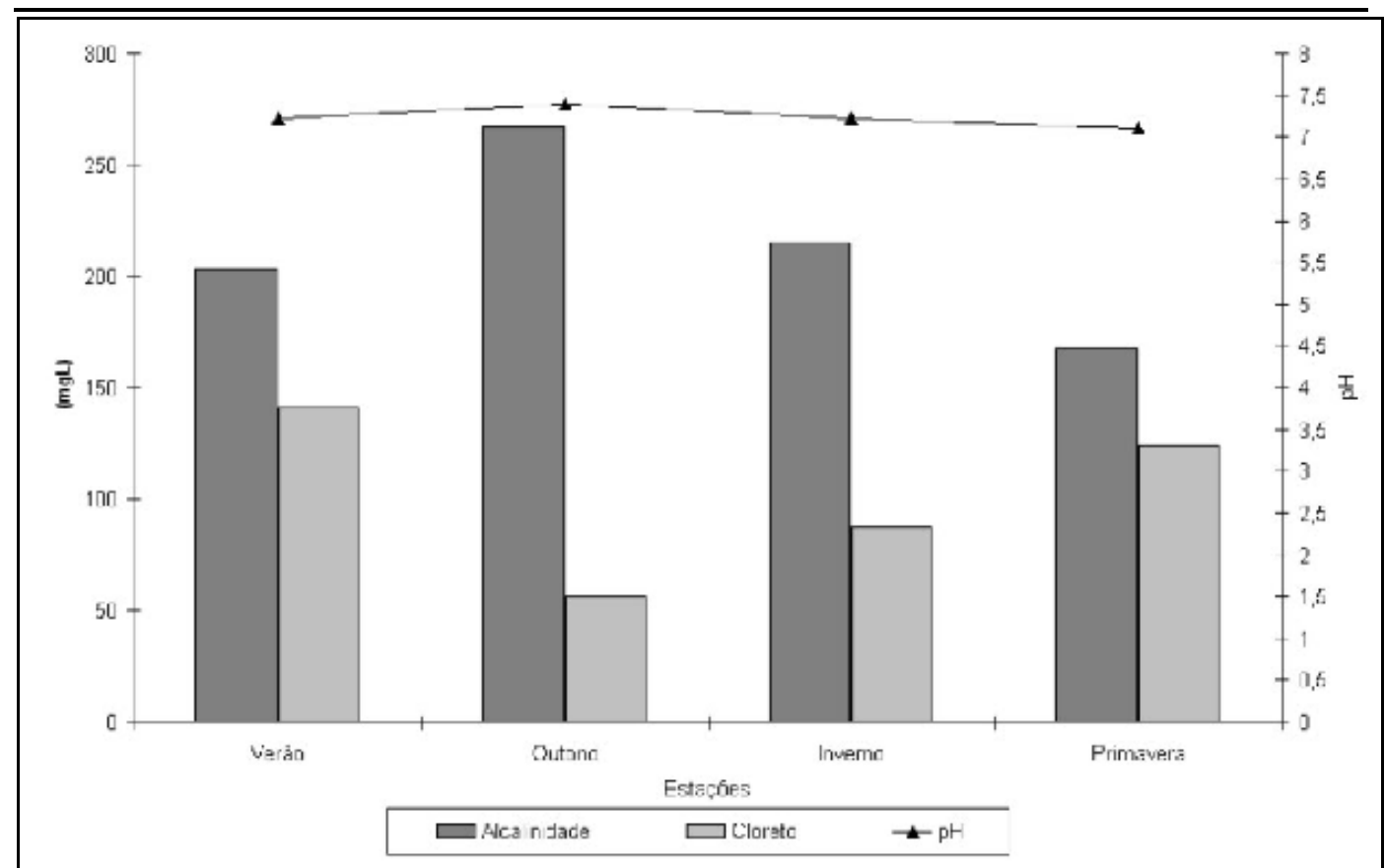

FIGURA 2: Valores médios de Alcalinidade, Cloreto e $\mathrm{pH}$, encontrados nas águas dos poços nas estações do verão, outono, inverno e primavera de 2004.

Como a alcalinidade está diretamente relacionada ao $\mathrm{pH}$, com a elevação das concentrações médias da alcalinidade no outono e inverno, o $\mathrm{pH}$ também apresentou uma ligeira elevação nesse período. A acidez acentuada no período chuvoso pode estar relacionada ao processo de lixiviação dos íons, que no início das chuvas percolam mais rápido, atingindo as águas subterrâneas.

O Número Mais Provável de bactérias termotolerantes acumuladas nos poços sofreu a influência da sazonalidade (Tabela 3 e Figura 3). Considerando que o período chuvoso na região compreende seis meses que são as estações da primavera e verão. Observou-se nesse período um aumento dos números de bactérias, favorecido pelos maiores índices pluviométricos e também pelas maiores temperatura médias, ao passo que as menores concentrações ocorreram no período seco e frio. A influência da sazonalidade também foi evidenciada por NOGUEIRA (2003), que 
CAPPI, N. et al. Avaliação sazonal da qualidade das águas subterrâneas da ... constatou elevados NMP de bactérias do grupo coliformes em água de poço no período quente e úmido e baixo no período seco e frio.

TABELA 3: Números mais prováveis de Coliformes Totais e Fecais encontrados nas Águas Subterrâneas da bacia do córrego Fundo em 2004

\begin{tabular}{ccccccccc}
\hline \multirow{8}{*}{ Es } & \multicolumn{7}{c}{ Estações/Coliformes (NMP/100 mL) } \\
\cline { 2 - 9 } & \multicolumn{2}{c}{ Verão } & \multicolumn{2}{c}{ Outono } & \multicolumn{2}{c}{ Inverno } & \multicolumn{2}{c}{ Primavera } \\
\cline { 2 - 9 } PT & $>30$ & $>30$ & $>30$ & $>30$ & $>30$ & $>30$ & $>30$ & $>30$ \\
P2 & $7,5 \times 10^{2}$ & $4,3 \times 10^{2}$ & $>30$ & $>30$ & $>30$ & $>30$ & $4,3 \times 10^{2}$ & $9,0 \times 10$ \\
P3 & $9,3 \times 10^{2}$ & $4,0 \times 10$ & $9,3 \times 10^{2}$ & $1,5 \times 10^{2}$ & $<30$ & $<30$ & $7,0 \times 10$ & $7,0 \times 10$ \\
P4 & $2,4 \times 10^{4}$ & $2,4 \times 10^{4}$ & $2,4 \times 10^{3}$ & $2,4 \times 10^{3}$ & $4,6 \times 10^{3}$ & $7,5 \times 10^{2}$ & $2,4 \times 10^{4}$ & $2,4 \times 10^{4}$ \\
P5 & $1,1 \times 10^{4}$ & $9,3 \times 10^{2}$ & $4,3 \times 10^{2}$ & $4,3 \times 10^{2}$ & $>30$ & $>30$ & $9,0 \times 10$ & $4,0 \times 10$ \\
P6 & $2,4 \times 10^{4}$ & $2,4 \times 10^{4}$ & $4,6 \times 10^{3}$ & $2,4 \times 10^{3}$ & $9,0 \times 10$ & $4,0 \times 10$ & $7,5 \times 10^{2}$ & $9,0 \times 10$ \\
P7 & $4,6 \times 10^{3}$ & $2,4 \times 10^{3}$ & $>30$ & $>30$ & $2,4 \times 10^{3}$ & $9,3 \times 10^{2}$ & $4,6 \times 10^{3}$ & $1,5 \times 10^{3}$ \\
\hline
\end{tabular}

Dos sete poços analisados o P3 e o P7 estão localizados em propriedades com usos diferenciados dentro da bacia. O P3 localizase na Fazenda da UEMS que além da utilização da água para consumo humano, também serve as granjas de suínos, aves, e os bebedouros a campo de bovinos e ovinos. O P7 é uma propriedade as margens do rio Aquidauana onde funciona um pesqueiro com grande freqüência de pessoas nos finais de semana e feriados. Considerando que a água do P3 fornecida na escola da Fazenda UEMS passa somente por bebedouros convencionais e que no P7 é fornecida sem tratamento prévio, as concentrações de cloretos e de coliformes são preocupantes. O P3 com condições construtivas adequadas, mas, localizado no médio curso da bacia em área susceptível à contaminação e o P7 localizado no baixo curso, pode estar recebendo contaminantes oriundos das atividades exercidas na bacia bem como, das condições construtivas inadequadas.

Considerando que as águas de poços em área rural dificilmente recebem algum tipo de tratamento, fica evidente o 
CAPPI, N. et al. Avaliação sazonal da qualidade das águas subterrâneas da ... risco à saúde dessas comunidades que além de consumirem a água para beber, cozinhar e uso doméstico em geral, também consomem verduras e frutas irrigadas com água contaminadas. De acordo com a Portaria 518 (BRASIL, 2004) e a Resolução 396 (BRASIL, 2008) a água para consumo humano deverá apresentar total ausência de coliformes termotolerantes. Para a irrigação, classe 2, e dessedentação animal, casse 3, a Resolução CONAMA (BRASIL, 2005), recomenda que a água para esses fins não poderá apresentar mais de 1000 bactérias por $100 \mathrm{~mL}$ de amostra. Portanto, com exceção do poço $\mathrm{P} 1$, os demais indicaram que, sem passar por tratamento, suas águas estão impróprias para o consumo humano.

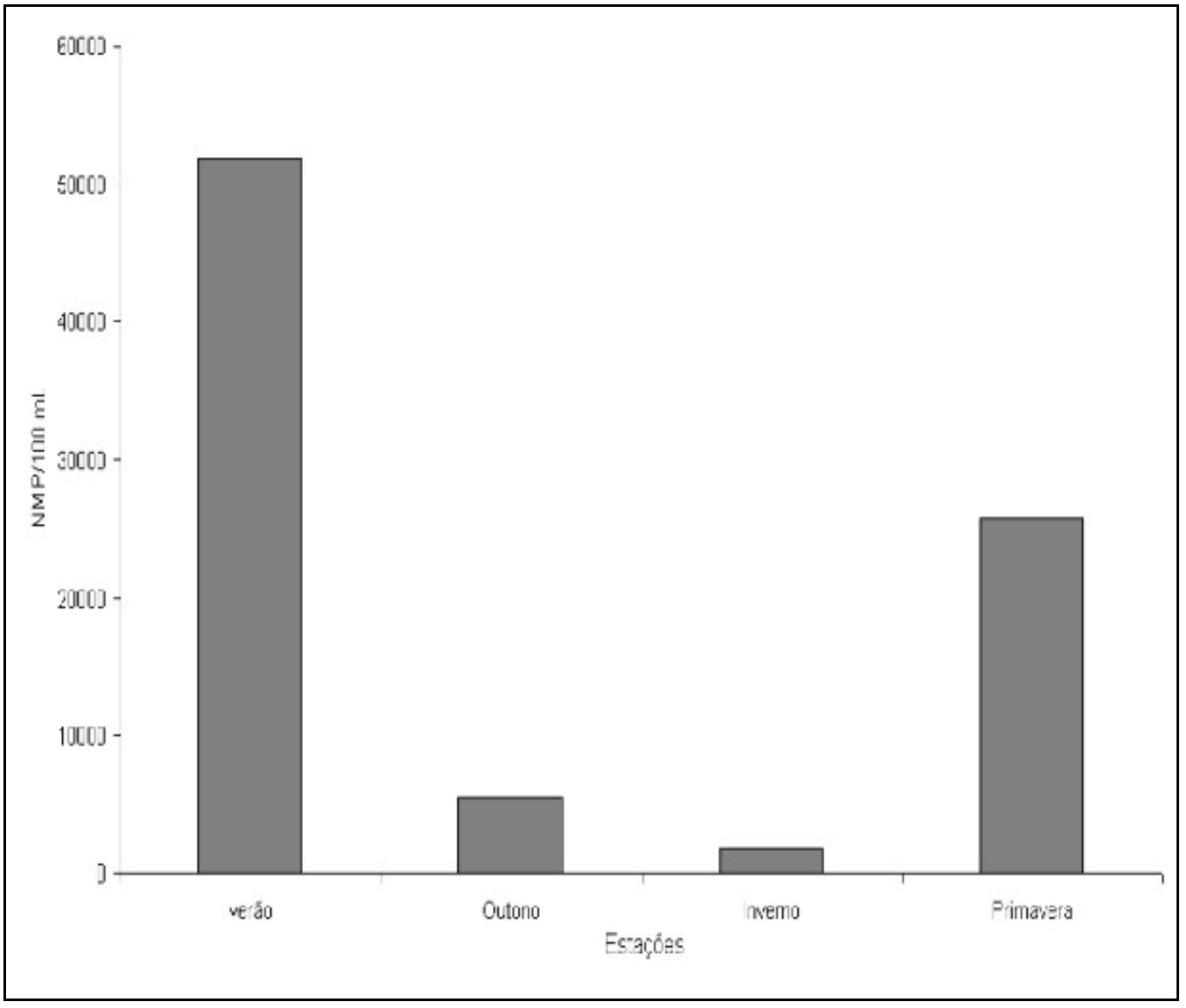

FIGURA 3: Número Mais Provável de bactérias termotolerantes acumuladas nas águas dos poços nas estações do verão, outono, inverno e primavera de 2004. 
CAPPI, N. et al. Avaliação sazonal da qualidade das águas subterrâneas da ...

Para os demais usos, considerando o NMP de bactérias termotolerantes acumuladas nas estações, somente no período seco e frio a água estaria própria para o consumo específico de irrigação de hortas e dessedentação animal.

As águas subterrâneas são intensamente exploradas em propriedades rurais, e constituem, em muitos casos, o recurso mais barato para essas comunidades. Faz parte da cultura dessas pessoas que a água de poço é filtrada e purificada naturalmente, portanto, quando não apresenta cor e sabor desagradável está livre de contaminantes e pode ser consumida dispensando tratamento prévio. Logo, o desconhecimento das formas de contaminação das águas subterrâneas, favorece a falta de proteção e conservação dos poços e das áreas de influência, bem como, o uso e ocupação desordenada das áreas de recarga dos aqüíferos que abastecem os poços, fatores que contribuem para a contaminação das águas.

A construção dos poços na maioria das vezes não segue as normas técnicas estabelecidas como: distância de fossas, de esgoto doméstico, de horta, curral, chiqueiro e deposito de lixo e construtivas, em especial de proteção lateral e de cobertura. São localizados via de regra nas dependências das casas ou muito próximos delas. Em algumas residências o esgoto que vai para a fossa é somente o proveniente do vaso sanitário. Os demais correm a céu aberto. As hortas são adubadas com dejeto de animais, as dependências dos animais como, galinheiro, chiqueiro e estábulo, não passam por limpeza periódica e armazenam dejetos, tornando estes locais como possíveis focos localizados de contaminação, facilitando o carreamento através da chuva de substâncias químicas e biológicas até as águas subterrâneas. Além da localização, as más condições construtivas dos poços também podem ser responsáveis pelos altos índices de contaminação encontrados. Normalmente, carecem de proteção sanitária, estando muitas vezes abertos ou cobertos de forma inadequada sem o anel de proteção no entorno permitindo a entrada de água do escoamento superficial. 
CAPPI, N. et al. Avaliação sazonal da qualidade das águas subterrâneas da ...

\section{Conclusão}

Considerando que a localização dos poços nas propriedades e as condições construtivas e de conservação são fatores de grande importância para a qualidade das águas, dos sete poços selecionados cinco eram construídos escavados $(71,4 \%)$ e dois tubulares $(28,6 \%)$. Os dois tubulares (P1 e P3) e um escavado (P7) captavam água por bombeamento $(42,8 \%)$, os demais escavados P2, P4, P5 e P6 (57,0\%) utilizavam balde para captar a água. A profundidade dos poços é outra característica importante na região, visto que os poços não chegam a $20 \mathrm{~m}$ de profundidade, em virtude do ambiente hidrogeomorfogeologico.

A alcalinidade total apresentou-se elevada nos poços P2, P3, P4, P5 e P6 em todas as estações analisadas e ultrapassou os valores máximos permitidos pela legislação nos poços $\mathrm{P} 4 \mathrm{em}$ todas as estações analisadas, P5 no outono, inverno e primavera e P6 no verão e outono.

As concentrações de cloreto foram superiores a $100 \mathrm{mgL}^{-1}$ em todos os poços no verão e na primavera com exceção do P1 com 57,5 $\mathrm{mgL}^{-1}$ e P3 com 15,0 $\mathrm{mgL}^{-1}$, mas inferiores ao VMP de $250 \mathrm{mgL}^{-1}$. No outono e inverno todos os poços apresentaram concentrações inferiores a $100 \mathrm{mgL}^{-1}$ com exceção do P3 com $145,0 \mathrm{mgL}^{-1}$ (inverno).

A sazonalidade influenciou nas concentrações de alcalinidade total, cloreto e $\mathrm{pH}$. Ao passo que a alcalinidade total apresentou-se elevada nas estações secas do ano (outono e inverno), as concentrações de cloretos mostrou-se reduzida em todos os poços e o $\mathrm{pH}$ também apresentou uma ligeira elevação nesse período.

O Número Mais Provável de bactérias do grupo coliformes também sofreu a influência da sazonalidade. No período chuvoso (primavera e verão), observou-se um aumento dos números de bactérias, favorecido pelos maiores índices pluviométricos e pelas temperaturas médias elevadas, ao passo que as menores concentrações ocorreram no período seco e frio (outono e inverno). 
CAPPI, N. et al. Avaliação sazonal da qualidade das águas subterrâneas da ...

Todos os poços apresentaram concentrações de bactérias do grupo coliformes elevadas, com exceção do poço $\mathrm{P} 1 \mathrm{em}$ todas as estações; P2 no outono e inverno; P3 no inverno e P7 no outono, que apresentaram o NMP de bactérias totais e termotolerantes inferior a 30 por $100 \mathrm{~mL}$ de amostra. Portanto, com exceção do poço $\mathrm{P} 1$, os demais indicaram que suas águas, sem passar por tratamento prévio, estão impróprias para o consumo humano.

Para os demais usos, considerando o NMP de bactérias termotolerantes acumuladas nas estações, somente no período seco as águas estariam próprias para o consumo específico de irrigação e dessedentação animal

\section{Referências bibliográficas}

APHA. Standard Methods for Examination of Water and Wastewater. 18 th ed. Washington, APHA/AWWA/WPCF, 1989.

APHA. Standard Methods for Examination of Water and Wastewater. 17 th ed. Washington, APHA/AWWA/WPCF, 1995. $1224 p$

ALVARES, C.M.B. Contribuição ao conhecimento do meio físico da região do lixão de São Paulo-SP, através de estudos geológicos, topográficos e químicos. 2000. 157p. Dissertação (Mestrado em Ciências da Engenharia Ambiental). Escola de Engenharia de São Carlos-Universidade de São Paulo, São Carlos, 2000

BAIRD, C. Química Ambiental. 2ed. Porto Alegre: Bookman, 2002. 622p.

BARCHA, S.F. Impactos antrópicos sobre recursos hídricos. In: Ciência e Desenvolvimento Sustentável. Seminário. São Paulo. BICRHEA/USP. 1997. p.104-117. 
CAPPI, N. et al. Avaliação sazonal da qualidade das águas subterrâneas da ... BAGANHA, C.A. Instrumentação eletromagnética no monitoramento de plumas de contaminação. 1996. 82p. Exame de qualificação (Doutorado em Geologia - Geociências e Meio Ambiente) UNESP/IGCE, 1996.

BRASIL-Ministério da Saúde. Portaria no 518, de 25 de março de 2004. DOU. No 59. Brasília, 26/03/2004. Seção 1. p.266.

BRASIL-Conselho Nacional do meio Ambiente. Resolução $\mathbf{n}^{\circ}$ 357, de março de 2005. Estabelece classificação para as águas doces, salobras e salinas do Território Nacional. DOU. $\mathrm{N}^{\circ} 53$. Seção 1. p.58., Brasília-DF, 18 /03/ 2005.

BRASIL.- Conselho Nacional do Meio Ambiente. Resolução no 396, de 03 de abril de 2008. Dispõe sobre a classificação e diretrizes ambientais para o enquadramento das águas subterrâneas e dá outras providências. DOU No 066. Brasília-DF. 07/04/2008, p. 66-68.

BRIGANTE, J; ESPINDOLA, E. L. G; POVINELLI, J; NOGUEIRA, A. M. de. Caracterização física, química e biológica da água do rio Mogi-Guaçu. In: Limnologia fluvial:um estudo no Rio Mogi-Guaçu. São Carlos:RiMa, 2003. p 55-76.

DMAE - Departamento Municipal de Água e Esgoto. Influência do lançamento do efluente de lagoas de estabilização das águas do Arroio do Salso. ECOS Pesquisas. Porto Alegre n.5. ano 2. outubro/2001.63p.

GELDREICH, E.E. Aspectos microbiológicos dos esgotos e dos seus processos de tratamento. In: Companhia Estadual de Tecnologia de Saneamento Básico e de Controle de Poluição das Águas. Desinfecção das águas. São Paulo, 1974. p. 115-134. 
CAPPI, N. et al. Avaliação sazonal da qualidade das águas subterrâneas da ...

LEAL, A. S. As águas subterrâneas no Brasil: ocorrência, disponibilidades e usos. In: O Estado das Águas no Brasil. Brasília: ANEEL, 1999, p.139-164.

MENDONÇA, C. R.;GRANADA, G.G.Coliformes em Açougues de Pelotas-RS. Revista Brasileira de Agrociências, v.5, $\mathrm{n}^{\mathrm{o}}$ 1, jan.abril, 1999, p.75-76

MORAES D. S de L; JORDÃO B. Q. Degradação de recursos hídricos e seus efeitos sobre a saúde humana. Rev. Saúde Pública, jun. 2002, v. 36, nº 3. p.370-374.

MORAIS, J. O. de. Geologia no planejamento ambiental: impactos na água. Revista de geologia, 1996, v.8, p.225-258.

OLIVEIRA, S. (Coord.). Relatório de qualidade ambiental no Estado de São Paulo. 1993. São Paulo:CETESB. 1994. 50 p. (Série Relatório)

NOGUEIRA, G. NAKAMURA, C. V.; TOGNIM, M. C. B.; ABREU FILHO, B. A.; DIAS FILHO, B. P. Qualidade microbiológica de água potável de comunidades urbanas e rurais, Paraná. Rev. Saúde Pública. 2003. n 37 v.2, p. 232 - 236

PINTO, A. L. Saneamento básico e suas implicações na qualidade das águas subterrâneas da Cidade de Anastácio (MS). 1998. 175p.Tese (Doutorado em Geociências) Universidade Estadual Paulista/Instituto de Geociências e Ciências Exatas, Rio Claro, 1998.

REBOUÇAS, A. C. Água subterrânea na região metropolitana de São Paulo. São Paulo: ABAS-Associação Brasileira de Águas subterrâneas, 2001. 24p. (Boletim informativo, 118). 
CAPPI, N. et al. Avaliação sazonal da qualidade das águas subterrâneas da ... RICHTER, C. A.; AZEVEDO NETTO, J. M. de. Tratamento de água: tecnologia atualizada. São Paulo: Edgard Blucher, 1991. $330 \mathrm{p}$.

SANT'ANNA NETO, J. L. O Caráter Transicional do Clima e a Diversidade da Paisagem Natural na Região de Aquidauana. In: II Semana de Estudos Geográficos: Desenvolvimento e Geografia. 1993, Aquidauana. Anais.... UFMS/CEUA, 1993, v.1, p.118-128.

SETTI, A. A., et al. Introdução ao Gerenciamento de recursos Hídricos. In: O Estado das Águas no Brasil, Brasília: ANEEL, 2001. CD-ROM.

SILVA. R de C. A.; ARAÚJO, T. M. de. Qualidade da água do manancial subterrâneo em áreas urbanas de feira de Santana (BA). Ciência \& Saúde coletiva, 2003, v.8 n.4, p. 1019-1028.

SOARES, J.B.; MAIA, A.C.F. Água: Microbiologia e tratamento. - Fortaleza: UFC, 1999. p.85-95.

VANDERZANT, C.; SPLITTSTOESSER, D. F. Compendium for the Microbiological Examination of Foods. Washington: Public Health Association, 3 rd Edition, 1992, 1219 p

TURKEWICZ, D. T. Implicações do uso, ocupação e manejo do solo na qualidade das águas superficiais da bacia do córrego Fundo. Aquidauana-MS. 2005. 112p. (Dissertação de Mestrado em Geografia). UFMS/CEUD. Dourados. 2005.

Recebido em dezembro de 2008

Aceito em março de 2010 